102

The Orgone's here, the Orgone's there Reich has found it everywhere. In death at least he is much calmer Wrapped in his last motoric armour.

Libido here, libido there, The healers sought it everywhere. The Guru movement ran along With wine and sin and sex and song And left a million miles behind Old fashioned healers of the mind. (A dull and dreary group who ply, With sceptic minds and squares of chi, Who randomize their boring trials Of Guru versus Roche's phials,

And end the day by bluntly stating 'Neither works on any rating'. 'Placebo lives' or so they say 'To cure us all another day'.)

As Sargant said, at side of bed, 'This is the place to cure the head'. (Celestial beds were all the rage When Mrs Siddons trod the stage. Come back Graham, all's forgotten, There's room for quacks, both good and rotten.) 'They all are cured by pill and potion',
BULLETIN OF THE ROYAL COLLEGE OF PSYCHIATRISTS, VOL 9, MAY 1985

Was once the true St Thomas' notion.

Another trial threw a spanner Into the works of bedside manner. And now one can no longer say 'I cured them by the bed today'.

The only thing we state at last Is ECT is safe and fast And penicillin cures the pox, Before the therapist unlocks

The traumas, complexes and binds That fill the sad unconscious minds Of those who suffer from the strain Of spirochaetes within the brain.

And here the pen jumped from my hand, No longer heeding my command, And started writing down: 'It's Stuff And Nonsense. That's enough I will not write another word,

You're sound asleep, your dream's absurd.

You seem to me a foolish berk,"

It's time you woke and got to work.'

* Believed to be Joseph Berke.

\title{
Society of Psychiatrists of South Africa (MASA): Position Statement
}

Council discussed this statement at its meeting on 20 March 1985. It was warmly received and the President was asked to write to the President of the Society of Psychiatrists of South Africa conveying Council's agreement with the views expressed in this statement.

On 31 January 1985 the Society of Psychiatrists declared that:

1. The Society of Psychiatrists recognizes and deplores potentially harmful psychological effects on the people of South Africa as a result of any form of discrimination based on race, colour, gender or creed. The Society does and will strive for the elimination of all forms of discrimination that adversely affect mental health.

2. The Society declares its opposition to any disparities in the quality of psychiatric services for all.

3. The Society declares its commitment to insist its members practise their profession as laid out in internationally accepted ethical codes in the Declaration of Helsinki, Hawaii and Tokyo and its determination to resist any form of abuse of psychiatric knowledge and skills for political ends or for any other purpose contrary to the best interests of the patients and their personal welfare.

4. The Society has by its representation and actions been responsible for many improvements in the services for all psychiatric patients in South Africa. The Society steadfastly declares its intention to continue these efforts.

President

Society of Psychiatrists of South Africa

\section{'Guidelines for Regional Advisers on Consultant Posts in Psychotherapy'}

The document prepared by the Psychotherapy Specialist Section, entitled 'Guidelines for Regional Advisers on Consultant Posts in Psychotherapy' (Bulletin, February 1985, 9, 40-1), was formally approved by the Court of Electors at its meeting in June 1984.
Professor Henry Walton has been awarded the Jofre Medal by the Spanish Society for Advancement of Psychiatry. 